\title{
PENINGKATAN HASIL BELAJAR EKONOMI DENGAN MENGGUNAKAN MEDIA PEMBELAJARAN AUDIO VISUAL PADA PESERTA DIDIK KELAS XI IPS 3 SMA NEGERI 2 PALANGKARAYA TAHUN PELAJARAN 2016/2017
}

\author{
Yayuk Sri Rahayu ${ }^{1}$, Miftahurrizqi ${ }^{2}$
}

\begin{abstract}
ABSTRAK
Pentingnya penelitian ini bertujuan untuk: (1) Meningkatkan aktivitasbelajar ekonomi setelah menggunakan media audio visual pada peserta didik kelas XI IPS 3 SMAN 2 Palangka Raya, (2) Meningkatkan hasil belajar ekonomi dengan menggunakan media audio visual peserta didik kelas XI IPS 3 SMAN 2 Palangka Raya. Metode penelitian yang digunakan dalam penelitian ini adalah penelitian tindakan kelas (PTK). Subjek dalam penelitian adalah kelas XI IPS 3 berjumlah 35 orang peserta didik terdiri dari 20 laki-laki dan 15 perempuan. Teknik pengumpulan data ada dua yaitu pre-test dan post-test. Hasil penelitian ini menunjukkan bahwa: (1) Aktivitas peserta didik selama proses pembelajaran dengan menggunakan media audio visual berupa video pembelajaran ekonomi menjadi lebih aktif. Hal ini ditunjukkan pada siklus I memperoleh skor 3,36 dengan kategori baik, dan pada siklus II mengalami peningkatan menjadi 3,8 dengan kategori baik, (2) Hasil belajar peserta didik kelas XI IPS 3 SMAN 2 Palangka Raya dengan menggunakan media audio visual mengalami peningkatan dari data awal rata-rata pra tindakan yaitu 67,5 dan ketuntasan secara klasikal 41,17\%. Nilai rata-rata pada siklus I yaitu 80,30 dan ketuntasan secara klasikal $70 \%$. Nilai rata-rata pada siklus II yaitu 91 dan ketuntasan secara klasikal $100 \%$.
\end{abstract}

(C) Universitas Muhammadiyah Palangkaraya

Kata Kunci: Hasil belajar ekonomi, media pembelajaran audio visual.

\section{PENDAHULUAN}

Pendidikan merupakan investasi jangka panjang yang memerlukan usaha dan dana yang cukup besar. Demikian halnya Indonesia yang menaruh harapan besar terhadap peserta didik dalam perkembangan masa depan bangsa ini, oleh karena itu dari sanalah tunas muda harapan bangsa sebagai generasi terbaik dibentuk.

Sebagaimana amanat sistem Pendidikan Nasional, Pasal 1 Ayat 3

Undang-Undang Republik Indonesia Nomor 20 tahun 2003, tentang Sistem Pendidikan Nasional mengamanatkan
"Keseluruhan komponen pendidikan saling terkait secara terpadu untuk mencapai tujuan Pendidikan Nasional”. Hal ini berarti bahwa pemerintah, orang tua murid, tenaga pendidik, siswa dan masyarakat merupakan suatu sistim yang tidak dapat dipisahkan satu sama lain untuk mencapai tujuan Pendidikan Nasional.

Arends (dalam Trianto, 2007:1) mengacu pada pendekatan pembelajaran, lingkungan pembelajaran dan pengelolaan kelas diharapkan setiap guru atau pendidik menyampaikan materi atau bahan ajarnya menggunakan 
media yang berteknologi. Setiap pendidik diharapkan mampu merancang media pembelajaran untuk membantu peserta didik mencapai tujuan pembelajaran.

Pembelajaran adalah merupakan proses komunikasi dua arah yaitu mengajar, mendidik yang dilakukan oleh pihak guru sebagai pendidik, sedangkan belajar dilakukan oleh peserta didik. Pembelajaran Menurut Undang-Undang Sistem Pendidikan Nasional (UUSPN) No.20 tahun 2003, "merupakan proses interaksi peserta didik dengan pendidik dan sumber belajar pada suatu lingkungan belajar".

Hasil belajar berkaitan dengan pencapaian dalam memperoleh kemampuan sesuai dengan tujuan khusus yang direncanakan. Dengan demikian, tugas utama guru dalam kegiatan ini adalah merancang instrumen yang dapat mengumpulkan data tentang keberhasilan peserta didik mencapai tujuan pembelajaran.

Berdasarkan data tersebut guru dapat mengembangkan dan memperbaiki program pembelajaran. Sedangkan, tugas seorang desainer dalam menentukan hasil belajar selain menentukan instrument beserta kriteria keberhasilannya. Hal ini perlu dilakukan, sebab dengan kriteria yang jelas dapat ditentukan apa yang harus dilakukan peserta didik dalam mempelajari isi atau bahan pelajaran.

Berdasarkan hasil observasi peneliti keberadaan media pembelajaran memang sangat baik di SMAN 2 Palangka Raya, dimana setiap ruangan berisi satu LCD. Hanya saja sebagian guru kurang berinovasi untuk menciptakan strategi atau inovasi baru dalam menyampaikan materi pelajaran kepada peserta didik sehingga lebih menarik perhatian peserta didik.

Masalah yang ditemui dalam hal ini masih kurangnya konsentrasi dalam belajar yang cenderung membuat peserta didik tidak fokus dalam belajar. Peserta didik kurang tertarik pada pelajaran ekonomi, ini banyak dipengaruhi faktor-faktor antara lain yaitu, dalam penjelasan materi masih kurang penguraian yang rinci sehingga sulit dipahami oleh peserta didik, kurangnya pemberian contoh-contoh yang nyata dalam proses pembelajaran. Selain itu juga mereka menggap bahwa pelajaran ekonomi membinggungkan karena sulit untuk memahami. Padahal salah satu mata pelajaran yang penting di sekolah adalah mata pelajaran ekonomi yang bertujuan untuk membekali peserta didik tentang konsep ekonomi agar peserta didik dapat mengetahui serta mengerti mengenai masalah ekonomi dalam kehidupan sehari-hari terutama yang terjadi dilingkungan keluarga, desa, kecamatan, kabupaten, provinsi, maupun nasional.

Media merupakan hal yang baik untuk dikembangkan dalam proses belajar mengajar. Media merupakan salah satu inovasi pembelajaran yang tidak membuat peserta didik monoton dalam belajar (melihat dan mendengarkan). Dalam hal ini peneliti menggunakan media audio visual dalam proses pembelajaran untuk meningkatkan hasil belajar. Dengan menggunakan audio visual dalam proses belajar mengajar diharapkan mampu menumbuhkan aktivitas peserta 
didik dalam belajar. Media audio visual yaitu media pandang dengar. Media audio visual akan menjadikan penyajian bahan ajar kepada peserta didik semakin lengkap dan optimal sesuai dengan modalitas belajar peserta didik sehingga diharapkan peserta didik akan lebih paham akan materi pembelajaran sehingga hasil belajar akan lebih meningkat. Selain itu media audio visual ini juga tidak hanya digolongkan sebagai pengalaman belajar yang diperoleh dari penginderaan, tetapi sebagai alat teknologis yang bisa memperkaya serta memberikan pengalaman bersifat konkrit kepada peserta didik.

Berdasarkan hasil pengamatan pada hasil ulangan tengah semester (UTS) peserta didik masih ada yang belum mencapai kriteria ketuntasan minimal (KKM) yang telah di tentukan oleh pihak SMAN 2 Palangkaraya pada mata pelajaran Ekonomi yaitu 80 . Adapun jumlah peserta didik sebanyak 35 peserta didik kelas XI IPS 3 SMAN 2 Palangkaraya dimana terdapat sebanyak 54\% (19 peserta didik) yang belum mencapai nilai Kriteria Ketuntasan Minimal (KKM), 19 peserta didik mendapatkan nilai 50 sampai 75 dari 35 peserta didik, sedangkan yang $46 \%$ (16 peserta didik) dapat mencapai nilai Kiteria Ketuntasan Minimal (KKM) pada kelas XI IPS 3 SMAN 2 Palangkaraya. Hal ini dilihat dari buku jurnal guru mata pelajaran Ekonomi. (sumber data: guru bidang studi Ekonomi kelas XI SMAN 2 Palangkaraya).

Hasil belajar peserta didik yang belum sesuai dengan yang diharapkan dibawah nilai KKM (belum tuntas), sedangkan menurut guru ekonomi kelas XI IPS 3 SMA Negeri 2 Palangka Raya nilai Kriteria Ketuntasan Minimal (KKM) untuk pelajaran ekonomi adalah 80. Dan data tersebut peneliti dapat dari guru mata pelajaran ekonomi dimana nilai rata-rata ulangan harian pada kelas XI IPS 3 masih jauh di bawah nilai KKM.

Menurut Rusman dkk (2011:169) mengatakan "media adalah pengantar pesan dari pengirim ke penerima pesan, dengan demikian media merupakan wahana penyalur informasi belajar atau penyalur pesan".

Menurut Azhar Arsyad (2013:2) mengatakan "media adalah bagian yang tidak terpisahkan dari proses belajar mengajar demi tercapainya tujuan pendidikan pada umumnya dan tujuan pembelajaran di sekolah pada khususnya".

Menurut Rusman dkk (2011:172) manfaat media pembelajaran dalam proses pembelajaran adalah sebagai berikut:

1) Pembelajaran akan lebih menarik perhatian peserta didik sehingga dapat menumbuhkan motivasi belajar.

2) Materi pembelajaran akan lebih jelas maknanya sehingga dapat lebih dipahami oleh peserta didik dan memungkinkan peserta didik menguasai tujuan pembelajaan lebih baik

3) Metode pembelajaran akan lebih bervariasi, tidak semata-mata komunikasi verbal melalui penuturan kata-kata oleh guru, sehingga siswa tidak bosan dan guru tidak kehabisan 
tenaga, apalagi bila guru harus mengajar untuk setiap jam pelajaran.

4) Peserta didik lebih banyak melakukan kegiatan belajar, sebab tidak hanya mendengarkan uraian guru, tetapi juga aktivitas lain seperti mengamati, melakukan, mendemonstrasikan, dan lain-lain.

Menurut Hamdani (2011: 249), yaitu: "Media audio visual merupakan kombinasi audio dan visual atau bisa disebut media pandang-dengar". Dengan demikian, media pembelajaran audio visual merupakan media berupa

\section{METODE PENELITIAN}

Dalam penelitian ini metode yang sesuai digunakan untuk meningkatkan hasil belajar siswa yaitu penelitian tindakan kelas. Penelitian Tindakan kelas (PTK) dalam bahasa inggris dikenal dengan beberapa istilah, yaitu: Classroom Research Hopkins.

Kegiatan PTK menurut Kemmis dan Mc Taggart (dalam Badrujaman dan Hidayat (2010:10), dilakukan dalam beberapa siklus, setiap siklus terdiri dari empat langkah, yaitu perencanaan, tindakan, pengamatan, dan refleksi.

Dalam melakukan penelitian ini peneliti tidak hanya hadir pada saat jadwal mengajar melainkan selalu aktif memantau atau meneliti peserta didik sekalipun di luar jam pelajaran guna memaksimalkan hasil penelitian. Dengan menggunakan pendekatan PTK, kedudukan peneliti dalam penelitian ini merupakan faktor yang sangat menentukan. Oleh sebab itu peneliti bertindak secara langsung sebagai pendidik dalam proses pengumpul data. Kedudukan peneliti sebagai pendidik alat yang mengabungkan penggunaan suara dan penglihatan dalam pembelajaran.

Menurut Hamdani (2011:249), "media Audio Visual merupakan kombinasi audio dan visual atau bisa disebut media pandang-dengar".

Menurut Sanjaya (2013:179), "media audio visual diantaranya adalah rekaman video, slide suara. Media audio visual lainnya yakni jenis-jenis media audio visual seperti: media video dan media komputer".

seakaligus pengumpul data, maka peneliti harus terus berada dan terlibat langsung dalam penelitian dan obyek yang akan diteliti dengan maksud untuk mengumpulkan data terkait permasalahan yang diteliti. Tujuannya untuk memperoleh data yang benarbenar objektif dan menambah data itu sendiri.

Sukardi (2009:80) menjelaskan bahwa "observasi adalah instrumen lain yang sering di jumpai dalam penelitian pendidikan. Dalam pendidikan observasi menjadi kegiatan utama".

Margono (2010:56) mengemukakan bahwa: "tes adalah seperangkat rangkaian (stimulasi) yang diberikan kepada seseorang dengan maksud untuk bisa mendapat jawaban yang dapat dijadikan dasar bagi pendapatan skor angka".

Untuk mengetahui keekfektifan penggunaan media Audio Visual dalam kegiatan pembelajaran perlu diadakan analisis data. Penelitian ini menggunakan pendekatan kuantitatif dan kualitatif. Pendekatan kuantitatif adalah suatu metode penelitian yang 
bersifat menggambarkan kenyataan atau fakta sesuai dengan data yang diperoleh sesuai dengan tujuan untuk mengetahui

\section{HASIL DAN PEMBAHASAN}

Hasil belajar peserta didik sejak tes awal sampai dengan penerapan media audio visual pada siklus I dan siklus II dapat dilihat pada tabel berikut:

\section{Tabel 1}

Hasil Belajar Peserta Didik Pada Pembelajaran Siklus I dan

Gambar 1

Hasil Belajar Peserta Didik Pada

Pembelajaran Siklus I dan Siklus II

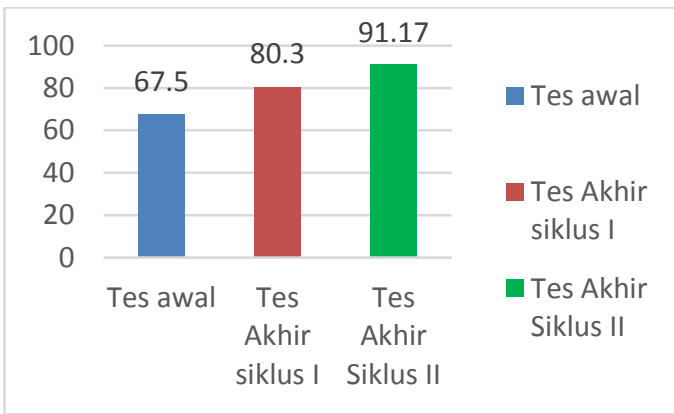

Berdasarkan tabel diatas maka dapat diketahui bahwa hasil belajar peserta didik mengalami peningkatan pada setiap siklusnya. Hal ini menunjukkan bahwa penggunaan media audio visual dapat digunakan dan tepat untuk meningkatkan hasil belajar peserta didik.

Berdasarkan analisis data yang dilakukan terhadap hasil belajar peserta

\section{KESIMPULAN}

Berdasarkan hasil penelitian, maka dapat disimpulkan beberapa hal sebagai berikut:

1. Peserta didik kelas XI IPS-3 SMAN 2 Palangka Raya lebih aktif pada saat pembelajaran Ekonomi hasil belajar yang dicapai oleh peserta didik. Sedangkan pendekatan kualitatif adalah berupa nilai belajar peserta didik.

Siklus II

\begin{tabular}{|c|c|c|c|}
\hline $\begin{array}{c}\text { No } \\
\cdot\end{array}$ & $\begin{array}{c}\text { D } \\
\text { a }\end{array}$ & Skor & $\begin{array}{c}\text { Sk } \\
\text { or }\end{array}$ \\
\hline 1 & Tes awal & 67,5 & 100 \\
\hline 2 & Tes Akhir & 80,30 & 100 \\
\hline 3 & Tes Akhir & 91,17 & 100 \\
\hline
\end{tabular}

didik, maka dapat diperoleh hasil belajar peserta didik dari tes awal, tes akhir siklus I dan tes akhir siklus II. Pada tes awal, hasil belajar peserta didik memperoleh nilai rata-rata 67,5 (dibawah $\mathrm{KKM} \geq 80$ ) dengan ketuntasan klasikal 41,17\% dengan kriteria kurang tercapai. Pada siklus I hasil belajar peserta didik memperoleh nilai rata-rata 80 dengan ketuntasan klasikal $70 \%$ dengan kriteria kurang tercapai. Pada siklus II meningkat hasil belajar peserta didik memperoleh nilai rata-rata 91 dengan ketuntasan klasikal 100\% dengan kriteria sangat tercapai. Berdasarkan hasil penelitian tersebut maka ada peningkatan hasil belajar Ekonomi peserta didik dengan menggunakan media pembelajaran audio visual.

dengan menggunakan media pembelajaran audio visual. Pada siklus I, aktivitas peserta didik memperoleh skor rata-rata 3,36 dengan kriteria baik.kemudian pada siklus II meningkatkan menjadi 3,8 dengan kriteria baik. Penggunaan 
media pembelajaran audio visual pada pembelajaran Ekonomi melibatkan peserta didik secara aktif dalam proses pembelajaran.

2. Ada peningkatan hasil belajar Ekonomi peserta didik kelas XI IPS-3 SMAN 2 Palangka Raya lebih aktif pada saat pembelajaran Ekonomi dengan menggunakan media pembelajaran audio visual. Pada tes awal, hasil belajar peserta

\section{DAFTAR PUSTAKA}

Arsyad, Azhar. (2013). Media Pembelajaran. Jakarta: PT Raja Grafmdo Persada.

Hamdani. (2011). Startegi Belajar Mengajar.Bandung: Pustaka Setia.

Margono.(2010). Metedologi Penelitian

Pendidikan. Jakarta: Rineka Cipta

Rusman, dkk. (2011). Pembelajaran

Berbasis Teknologi Informasi dan

Komunikasi. Jakarta: PT

RajaGrafindo Persada didik memperoleh nilai rata-rata 67,5 dengan ketuntasan klasikal 41,17\%. Pada siklus I hasil belajar peserta didik memperoleh nilai rata-rata 80 dengan ketuntasan klasikal 70\%. Siklus II hasil belajar peserta didik memperoleh nilai rata 91 dengan ketuntasan klasikal $100 \%$.

Sanjaya,Wina. (2013). Perencanaan dan

Desain Sistem Pembelajaran.

Jakarta: Kencana Prenadamedia Group.

Sukardi. (2009). Metodologi Penelitian Pendidikan Kompetensi dan Praktiknya. Jakarta: Bumi Aksara Trianto. (2007). Model-Model Pembelajaran Inovatif Berorientasi Konstruktivistik. Jakarta: Prestasi Pustaka. 